\title{
ПЕРСПЕКТИВИ ВИКОРИСТАННЯ МЕТОДУ ЛАЗЕРНОЇ АВТОФЛУОРЕСЦЕНТНОЇ МІКРОСКОПІЇ ГІСТОЛОГІНИХ ЗРІЗІВ ПРЯМОГО М'ЯЗУ ЖИВОТА ДЛЯ ДІАГНОСТИКИ ГОСТРОЇ КРОВОВТРАТИ
}

\section{А-В. С. Сивокоровська}

Вищий державний навчальний заклад України "Буковинський державний медичний університет", Чернівці

\begin{abstract}
Ключові слова: лазерна поляриметрія, автофлуоресчентна мікроскопія, гостра крововтрата, судова медицина.

Клінічна та експериментальна патологія Т.18, №2 (68). C.139-143.

DOI: $10.24061 / 1727-$ 4338.XVIII.2.68.2019.253

E-mail:

syvokorovska.av @)bsmu.edu.ua

Мета роботи - встановлення можливостей діагностики гострих крововтрат $з$ використанням методу лазерної автофлуоресцентної мікроскопї гістологічних зрізів прямого м'язу живота.

Матеріал та методи. Об'єктом дослідження були нативні гістологічні зрізи прямого м'яза живота товщиною 30мкм з різним ступенем крововтрати. Для кожного зразка за допомогою спектрально-селективної флюоресиентної мікроскопії визначались координантні структури маплазерної автофлуоресиениії.

Результати. 3 одержаних даних про динаміку та сценарій зміни статистичних параметрів розподілів величини інтенсивності мап лазерної автофлуоресиениії видно, щуо значення статистичних параметрів - середнього, дисперсії, асиметрії та ексиесу, які характеризують ступень деполяризації лазерного випромінювання гістологічними зрізами ПМЖ померлих, змінюються у межах об'єму крововтрати від Одо 2500 мм3. Чутливим до змін інтенсивності лазерної автофлуоресцениії зразків ПМЖ померлих з різним ступенем крововтрати виявився весь набір статистичних моментів 1-4-го порядків.

Висновки. Отримані результати підтверджують можливість використання методу лазерної автофлуоресцентної мікроскопії гістологічних зрізів прямого м'яза живота для діагностики гострої крововтрати та у перспективі відкриває можливості дослідження інших біологічних тканини з фібрилярною структурою та різним ступенем крововтрати.
\end{abstract}

Ключевые слова: табакокурение, осложнения, дисфункиия плаценты, плацентарный лактоген.

Клиническая и экспериментальная патология Т.18, №2 (68). C.139-143.

\section{ПЕРСПЕКТИВЫ ИСПОЛЬЗОВАНИЯ МЕТОДА ЛАЗЕРНОЙ АВТОФЛУОРЕСЦЕНТНОЙ МИКРОСКОПИИ ГИСТОЛОГИЧЕСКИХ СРЕЗОВ ПРЯМОЙ МЫШЦЫ ЖИВОТА ДЛЯ ДИАГНОСТИКИ ОСТРОЙ КРОВОПОТЕРИ}

\section{А-В. С. Сивокоровская}

Цель работы - установление возможностей диагностики острых кровопотерь с использованием метода лазерной автофлуоресцентной микроскопии гистологических срезов прямой мышщь живота.

Материал и методы. Объектом исследования были нативные гистологические срезы прямой мышщы живота толщиной 30 мкм с разной степенью кровопотери. Для каждого образца с помощью спектрально-селективной флюоресцентной микроскопии определялись координантные структуры карт лазерной автофлуоресиеничии.

Результаты. Из полученных данных о динамике и сценарий изменения статистических параметров распределений величинь интенсивности карт лазерной автофлуоресценции видно, что значение статистических параметров -среднего, дисперсии, асимметрии и эксцесса, характеризующих степень деполяризации лазерного излучения гистологическими срезами ПМЖ умерших, изменяются в пределах

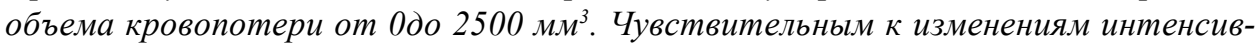
ности лазерной автофлуоресиеничи образиов ПМЖ умериих с разной степенью кровопотери оказался весь набор статистических моментов 1- 4-го порядков.

Выводы. Полученные результаты подтверждают возможность использования метода лазерной автофлуоресцентной микроскопии гистологических срезов прямой мышиы жсивота для диагностики острой кровопотери и в перспективе открывает возможности исследования других биологических тканей с фибриллярной структурой и разной степенью кровопотери.

\section{Key words:} PERSPECTIVES OF USING THE METHOD OF LASER AUTOFLUORESCENT laser polarimetry, autofluorescent microscopy, acute MICROSCOPY OF HISTOLOGICAL SECTIONS OF THE RECTUS ABDOMINAL MUSCLE FOR DIAGNOSTICS OF ACUTE BLOOD LOSS

A-V.S. Syvokorovska 
The objective of the paper was determination of diagnostics possibilities of acute blood loss using the laser autofluorescence microscopy of histological sections of the rectus abdominal muscle.

Material and methods. The object of the study were native histological sections of the rectus abdominal muscle of 30 micrometers thickness with various degree of the blood loss. The coordinate structures of the laser autofluorescence maps were determined for each sample using spectral-selective fluorescence microscopy.

Results. The value of statistical parameters - average, dispersion, asymmetry and kurtosis, characterizing the degree of depolarization of laser radiation by histological sections of the rectus abdominal muscle, varies within the volume of the blood loss from 0 to 2500 mm3. The whole set of parameters was sensitive to changes in the intensity of laser autofluorescence of samples of the rectus abdominal muscles with various degree of the blood loss.

Conclusion. The obtained results confirm the possibility of using the method of laser autofluorescence microscopy of the histological sections of the direct abdominal muscle for the diagnostics of acute blood loss, and in perspective discovers the possibility of studying other biological tissues with a fibrillary structure and different degree of the blood loss.

\section{Вступ}

Гостра крововтрата - одна з причин смерті, що доволі часто трапляється серед усіх травматичних випадків у практиці лікаря судово-медичного експерта. Усі патоморфологічні зміни органів при крововтраті $є$ неспецифічними, варіабельними та не дають відповідей на ряд питань, поставлених судово-слідчими органами перед експертом. Найбільш гостро стоїть питання про можливості виживання потерпілого при своєчасному наданні медичної допомоги.

На сьогодні успішно впроваджені в медичну практику методи лазерної поляриметрії для дослідження мікрорівня біологічних тканин [1-3]. У судово-медичній практиці можливості використання таких методів демонструють дослідження паренхіматозних органів, шкіри, мозку та рідин тіла для діагностики давності настання смерті та тілесних ушкоджень [3-6].
Встановити можливості діагностики гострих крововтрат із використанням методу лазерної автофлуоресцентної мікроскопії гістологічних зрізів прямого м'яза живота (ПМЖ).

\section{Матеріали і методи дослідження}

Залежно від рівня крововтрати $(\mathrm{V})$ розглядалися зразки гістологічних зрізів прямого м'яза живота 3 різним ступенем крововтрати. $\mathrm{V}=0 \mathrm{Mm}^{3}$ - група 1 - контрольна (35 зразків), а також наступні дослідні групи: $\mathrm{V}=500 \mathrm{Mm}^{3} \pm 100 \mathrm{Mm}^{3}-$ група 2 (20 зразків); $\mathrm{V}=1000 \mathrm{Mm}^{3} \pm$ $100 \mathrm{Mм}^{3}$ - група 3 (18 зразків); $\mathrm{V}=1500 \mathrm{Mm}^{3} \pm 100 \mathrm{Mm}^{3}-$

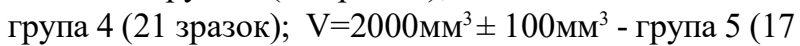
зразків); $\mathrm{V}=2500 \mathrm{Mм}^{3} \pm 100 \mathrm{Mм}^{3}$ - група 6 (16 зразків).

На рис. 1 представлена функціональна блок-схема спектрально-селективної лазерної автофлуоресцентної мікроскопії гістологічних зрізів структурованих біологічних тканин (БТ).

\section{Мета роботи}
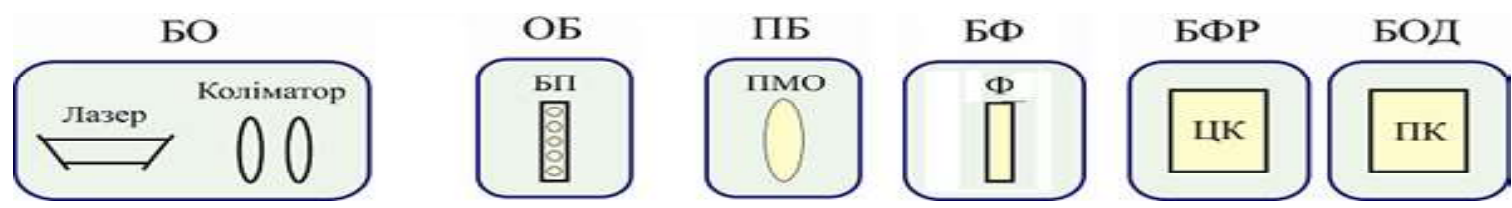

Рисунок 1. Функціональна блок-схема багатопараметричної спектрально-селективної лазерної автофлуоресцентної мікроскопії: 1- блок освітлення; 2- об'єктний блок; 3- проекційний блок; 4- блок спектральної фільтрації; 5- блок фотоелектронної ресстрації; 6- блок обробки даних

Тут:

1 - блок освітлення БО біологічних препаратів, який забезпечує формування паралельного з діаметром 2 мм поляризованого лазерного пучка з довжиною хвилі 0,405 мкм, який збуджує власну флуоресценцію флуорофорів БТ;

2 - об'єктний блок ОБ - мікроскопічний столик з двохкоординатним переміщенням, на якому закріплюється біологічний препарат (БП);

3 - проекційний блок ПБ, який за допомогою мікрооб'єктива МО (4X) забезпечує формування збудженого лазерним пучком автофлуоресцентного мікроскопічного зображення БП в площині цифрової камери;

4 - блок спектральної фільтрації БФ, який включає інтерференційні світлофільтри Ф для спектральної селекції збудженого афтолуоресцентного поліхроматичного випромінювання ансамблю флуорофорів БП;

5 - блок фотоелектронної реєстрації БФР мікроскопічних флуоресцентних зображень БП, який містить ЦК та забезпечує формування координатного цифрового розподілу величини інтенсивності в інтерфейсі комп'ютера;

6 - блок обробки даних БОД, який за допомогою персонального комп'ютера ПК забезпечує розрахунок величини статистичних моментів 1- 4-го порядків, які характеризують розподіли інтенсивності спектрально-селективної автофлуоресценції БП.

ISSN 1727-4338 https://www.bsmu.edu.ua 


\section{Результати та їх обговорення}

На рис. 2 приведені результати лазерної автофлуоресцентної мікроскопії (фрагменти (1),(3)) і гістограми (фрагменти (2),(4)) розподілів величини інтенсивності флуоресценції полікристалічних фібрилярних мереж гістологічних зрізів ПМЖ померлих з групи 1 (фрагменти (1),(2)) і групи 3 (фрагменти (3),(4)). Одержані результати лазерної автофлуоресцентної мікроскопії ілюструють наявність відмінностей між координатними розподілами інтенсивності мап лазерної автофлуоресценції (МЛА) гістологічних зрізів ПМЖ померлих 3 різним ступенем крововтрати.

Установлено, що гістограми розподілів величини інтенсивності МЛА (рис.2, фрагмент 4) гістологічних зрізів тканини ПМЖ з рівнем крововтрати $\left(\mathrm{V}=1000 \mathrm{MM}^{3}\right.$ $\left.\pm 100 \mathrm{Mм}^{3}\right)$ характеризуються меншим середнім значенням і діапазоном розкиду випадкових значень інтенсивності флуоресценції порівняно з аналогічними розпо-
1
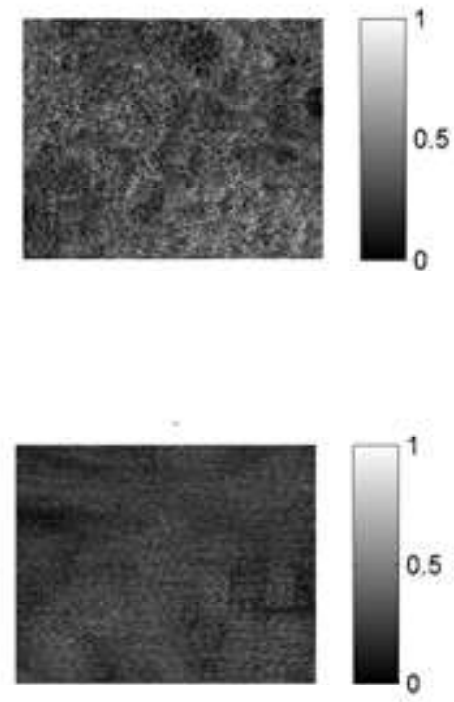

3
2
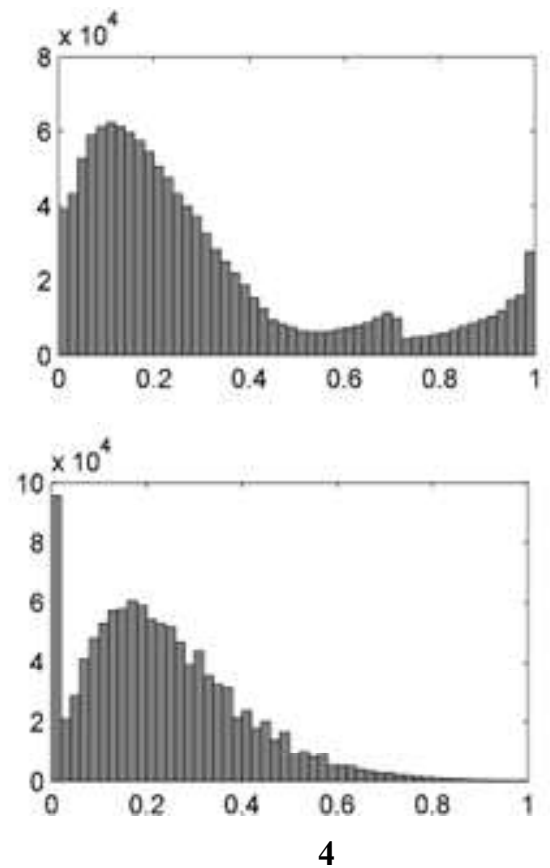

Рисунок 2. Мапи $(1,3)$ і гістограми $(2,4)$ розподілів величини інтенсивності лазерної автофлуоресценції гістологічних зрізів прямого м'яза живота контрольної $(1,2)$ та дослідної $(3,4)$ груп померлих

ділами МЛА, які визначені для зразків аналогічної тканини померлого без крововтрати (рис. 2, фрагмент (2)). Виявлений факт різної інтенсивності лазерної автофлуоресценції зразків ПМЖ можна пояснити із залученням даних спектрально-селективної флуоресцентної мікроскопії гістологічних зрізів біологічних тканин різних органів людини [6-8]. Тут показано, що головним чинником формування координатної структури МЛА концентрація формених елементів крові. Величина інтенсивності МЛА прямо пропорційна концентрації таких оптично анізотропних молекулярних структур гістологічного зрізу ПМЖ (рис. 2, фрагменти 1,3). Тому із збільшенням ступеня крововтрати (зменшенням концентрації формених елементів крові) знижується рівень інтенсивності лазерної авто флуоресценції [6-8]. У межах статистичного підходу до флуоресцентного аналізу зростання крововтрати супроводжується протилежними тенденціями - зменшенням середнього і дисперсії, які характеризують розподіли інтенсивності МЛА (рис. 2 , фрагменти 2,4). Навпаки, асиметрія та ексцес розподілів випадкових значень інтенсивності лазерної автофлуоресценції зразків ПМЖ померлих зростають.

Кількісно цей сценарій зміни розподілів величини інтенсивності лазерної автофлуоресценції оптично анізотропних фібрилярних мереж сукупності зразків гістологічних зрізів тканини ПМЖ померлих з різним ступенем крововтрати ілюструють статистичні моменти 1-4-го порядків, величини яких систематизовані в таблиці.

Установлено:

- діапазон зміни величини статистичних моментів 14-го порядків, які характеризують розподіли величини інтенсивності МЛА гістологічних зрізів ПМЖ, за рівнем крововтрати становить $0 \mathrm{Mм}^{3} \div 2500 \mathrm{Mм}^{3}$;

- величина статистичного моменту 1-го порядку $S M_{1}$ змінюється у межах діапазону зміни середніх значень від 0,31 до 0,105;

- величина статистичного моменту 2-го порядку $S M_{2}$ змінюється у межах діапазону зміни середніх значень від 0,27 до 0,04 ;

- величина статистичного моменту 3-го порядку $S M_{3}$ змінюється у межах діапазону зміни середніх значень від 0,85 до 1,49 ;

- величина статистичного моменту 4-го порядку $S M_{4}$ змінюється у межах діапазону зміни середніх значень від 0,45 до 1,74 .

Залежності, що наведені на рис. 3, кількісно ілюструють діаграми динаміки зміни набору статистичних моментів $S M_{1 ; 2 ; 3 ; 4}$, які характеризують розподіли величини інтенсивності МЛА зразків гістологічних зрізів

ISSN 1727-4338 https://ww.bsmu.edu.ua 
Таблиця

Статистична структура мап інтенсивності автофлуоресценції гістологічних зрізів ПМЖ померлих $з$ різним ступенем крововтрати

\begin{tabular}{|c|c|c|c|}
\hline Крововтрата, мм $^{3}$ & 0 & $500 \mathrm{MM}^{3} \pm 100 \mathrm{MM}^{3}$ & $1000 \mathrm{MM}^{3} \pm 100 \mathrm{MM}^{3}$ \\
\hline Середнє, $S M_{1}$ & $0.31 \pm 0.013$ & $0.27 \pm 0.011$ & $0.23 \pm 0.001$ \\
\hline Критерії, $t, p$ & $p \prec 0.05$ & $p \prec 0.05$ & $p \prec 0.05$ \\
\hline Дисперсія, $S M_{2}$ & $0.27 \pm 0.011$ & $0.21 \pm 0.001$ & $0.16 \pm 0.0006$ \\
\hline Критерії, $t, p$ & $p \prec 0.05$ & $p \prec 0.05$ & $p \prec 0.05$ \\
\hline Асиметрія, $S M_{3}$ & $0.85 \pm 0.041$ & $0.97 \pm 0.044$ & $1.09 \pm 0.048$ \\
\hline Критерії, $t, p$ & $p \prec 0.05$ & $p \prec 0.05$ & $p \prec 0.05$ \\
\hline Ексцес, $S_{4}$ & $0.45 \pm 0.021$ & $0.71 \pm 0.034$ & $0.97 \pm 0.043$ \\
\hline Критерії, $t, p$ & $p \prec 0.05$ & $p \prec 0.05$ & $p \prec 0.05$ \\
\hline Крововтрата, мм ${ }^{3}$ & $1500 M^{3} M^{3} \pm 100 M M^{3}$ & $2000 M^{3} \pm 100 M M^{3}$ & $2500 \mu M^{3} \pm 100 \mu^{3}$ \\
\hline Середнє, $S M_{1}$ & $0.18 \pm 0.008$ & $0.14 \pm 0.006$ & $0.105 \pm 0.004$ \\
\hline Критерії, $t, p$ & $p \prec 0.05$ & $p \prec 0.05$ & $p \prec 0.05$ \\
\hline Дисперсія, $S M_{2}$ & $0.105 \pm 0.004$ & $0.08 \pm 0.300$ & $0.04 \pm 0.002$ \\
\hline Критерії, $t, p$ & $p \prec 0.05$ & $p \prec 0.05$ & $p \prec 0.05$ \\
\hline Асиметрія, $S M_{3}$ & $1.22 \pm 0.051$ & $1.34 \pm 0.055$ & $1.49 \pm 0.058$ \\
\hline Критерії, $t, p$ & $p \prec 0.05$ & $p \prec 0.05$ & $p \prec 0.05$ \\
\hline Ексцес, $\mathrm{SM}_{4}$ & $1.26 \pm 0.053$ & $1.48 \pm 0.048$ & $1.74 \pm 0.077$ \\
\hline Критерії, $t, p$ & $p \prec 0.05$ & $p \prec 0.05$ & $p \prec 0.05$ \\
\hline
\end{tabular}

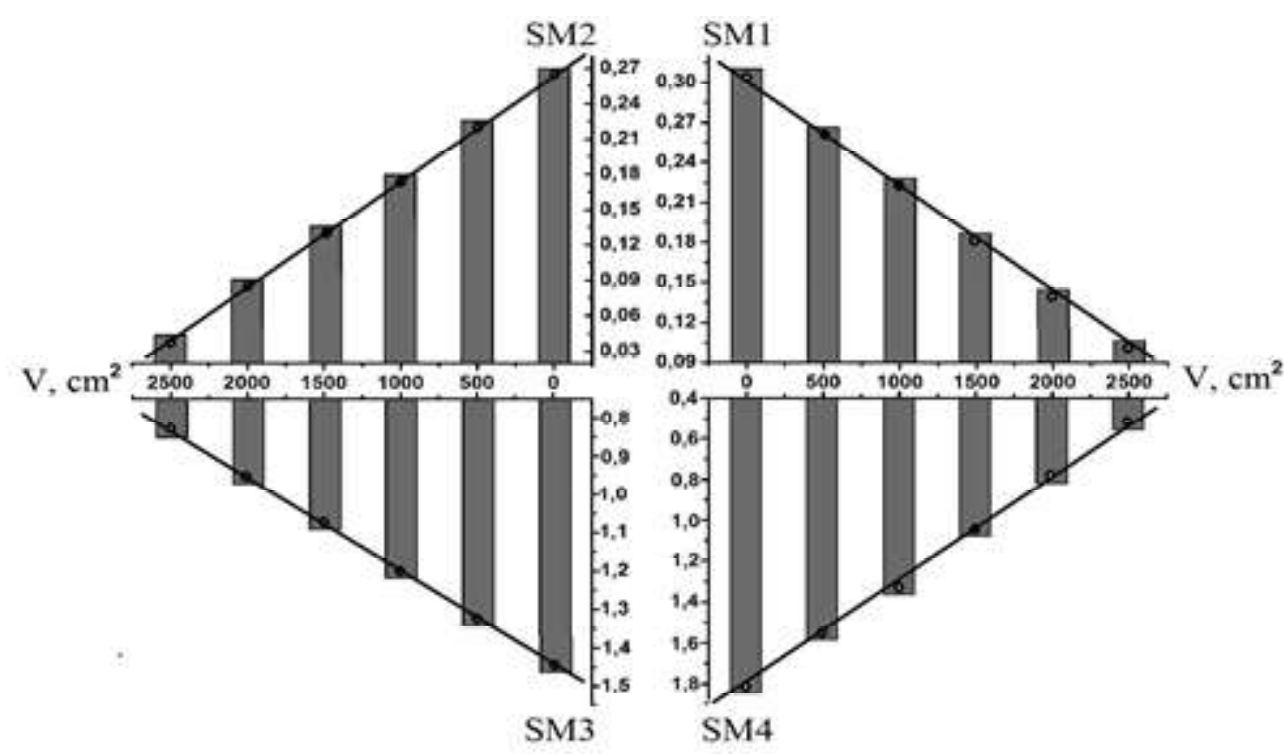

Рисунок 3. Залежності величини середнього (SM1), дисперсії (SM2), асиметрї̈ (SM3) та ексцесу (SM4), які характеризують мапи інтенсивності автофлуоресценції гістологічних зрізів прямого м'язу живота померлих з різним ступенем крововтрати

ПМЖ усіх груп померлих.

\section{Висновки}

3 одержаних даних про динаміку та сценарій зміни статистичних параметрів розподілів величини інтенсивності МЛА (рис. 3) видно, що значення статистичних параметрів - середнього (1), дисперсії (2), асиметрії (3) та ексцесу (4), які характеризують ступінь деполяризації лазерного випромінювання гістологічними зрізами ПМЖ померлих, змінюються у межах об'єму крововтрати $0 \mathrm{Mм}^{3} \pm 2500 \mathrm{Mм}^{3}$. Чутливим до змін інтенсивності

ISSN 1727-4338 https://www.bsmu.edu.ua лазерної автофлуоресценції зразків ПМЖ померлих 3 різним ступенем крововтрати виявився весь набір статистичних моментів 1-го - 4-го порядків.

\section{Перспективи подалыших досліджень}

Отримані результати підтверджують можливість використання вказаного методу для дослідження гістологічних зрізів ПМЖ померлих внаслідок гострої крововтрати та у перспективі відкриває можливості дослідження інших біологічних тканини з фібрилярною структурою та різним ступенем крововтрати.

Клінічна та експериментальна патологія. 2019. Т.18, №2 (68) 


\section{Список літератури}

1.Ушенко ОГ, Бачинський ВТ, редактори. Основи лазерної поляриметрії: Чернівці; 2010. Частина 2, Патоморфологічні зміни біологічних тканин; 372 с.

2.Ushenko YuA, Syvokorovska AV, Gorsky MP, Tomka YuA, Sokolnuik SO, Bakun O, et al. System of 3D Mueller-matrix reconstruction of fibrillar networks of biological tissues of various morphological structure and physiological state. Proc SPIE. 2018;10728:107280R doi: https://doi.org/10.1117/12.2320535

3.Ushenko AG, Dubolazov AV, Ushenko VA, Ushenko YUA, Sakhnovskiy MYu, Balazyuk VN, et al. Polarization-correlation optical microscopy of anisotropic biological layers. Proc SPIE 2016;9971:99712C. doi: https://doi.org/10.1117/12.2237926

4.Garazdyuk MS, Bachinskyi VT, Vanchulyak OY, Ushenko AG, Dubolazov OV, Gorsky MP. Polarization-phase images of liquor polycrystalline films in determining time of death. Appl Opt 2016;55(12):B67-71. doi: 10.1364/AO.55.000B67

5.Ushenko YuO; Dubolazov OV, Ushenko VO; Zhytaryuk VG, Prydiy OG; Pavlyukovich N, et al. Statistical analysis of polarization interference images of biological fluids polycrystalline films in the tasks of optical anisotropy weak changes differentiation. Proc SPIE. 2018;10612: 106121Q. doi:10.1117/ 12.2305361

6.Ushenko AG, Pishak VP. Laser Polarimetry of Biological Tissues: Principles and Applications. In: Tuchin VV, editors. Coherent-Domain Optical Methods. Biomedical Diagnostics, Environmental and Material Science. Vol 1. Boston: Kluwer Academic Publishers; 2004, p. 93-136.

7.Angelsky OV, Ushenko AG, Ushenko YuA, Pishak VP, Peresunko AP. Statistical, Correlation and Topological Approaches in Diagnostics of the Structure and Physiological State of Birefringent Biological Tissues. In: Tuchin VV, editors. Handbook of Photonics for Biomedical Science. 1 ed. CRC Press; 2010, p 283-322.

8.Ushenko YA, Boychuk TM, Bachynsky VT, Mincer OP. Diagnostics of Structure and Physiological State of Birefringen Biological Tissues: Statistical, Correlation and Topological Approaches. In: Tuchin VV, editors. Coherent-Domain Optical Methods. Biomedical Diagnostics, Environmental and Material Science. 2nd ed. New York: Springer; 2013, p. 107-48.

\section{References}

1.Ushenko OH, Bachyns'kyi VT, redaktory. Osnovy lazernoi poliarymetrii: Chernivtsi; 2010. Chastyna 2, Patomorfolohichni zminy biolohichnykh tkanyn [Pathomorphological changes in biological tissues]; 372 p. . (in Ukrainian).

2.Ushenko YuA, Syvokorovska AV, Gorsky MP, Tomka YuA, Sokolnuik SO, Bakun O, et al. System of 3D Mueller-matrix reconstruction of fibrillar networks of biological tissues of various morphological structure and physiological state. Proc SPIE. 2018;10728:107280R doi: https://doi.org/10.1117/12.2320535

3.Ushenko AG, Dubolazov AV, Ushenko VA, Ushenko YUA, Sakhnovskiy MYu, Balazyuk VN, et al. Polarization-correlation optical microscopy of anisotropic biological layers. Proc SPIE. 2016;9971:99712C. doi: https://doi.org/10.1117/12.2237926

4.Garazdyuk MS, Bachinskyi VT, Vanchulyak OY, Ushenko AG, Dubolazov OV, Gorsky MP. Polarization-phase images of liquor polycrystalline films in determining time of death. Appl Opt. 2016;55(12):B67-71. doi: 10.1364/AO.55.000B67

5.Ushenko YuO; Dubolazov OV, Ushenko VO; Zhytaryuk VG, Prydiy OG; Pavlyukovich N, et al. Statistical analysis of polarization interference images of biological fluids polycrystalline films in the tasks of optical anisotropy weak changes differentiation. Proc SPIE. 2018;10612: 106121Q. doi:10.1117/12.2305 361

6.Ushenko AG, Pishak VP. Laser Polarimetry of Biological Tissues: Principles and Applications. In: Tuchin VV, editors. Coherent-Domain Optical Methods. Biomedical Diagnostics, Environmental and Material Science. Vol 1. Boston: Kluwer Academic Publishers; 2004, p. 93-136.

7.Angelsky OV, Ushenko AG, Ushenko YuA, Pishak VP, Peresunko AP. Statistical, Correlation and Topological Approaches in Diagnostics of the Structure and Physiological State of Birefringent Biological Tissues. In: Tuchin VV, editors. Handbook of Photonics for Biomedical Science. 1 ed. CRC Press; 2010, p. 283-322

8.Ushenko YA, Boychuk TM, Bachynsky VT, Mincer OP. Diagnostics of Structure and Physiological State of Birefringent Biological Tissues: Statistical, Correlation and Topological Approaches. In: Tuchin VV, editors. Coherent-Domain Optical Methods. Biomedical Diagnostics, Environmental and Material Science. 2nd ed. New York: Springer; 2013, p. 107-48.

\section{Відомості про автора:}

Сивокоровська А-В. С. - аспірант кафедри судової медицини та медичного правознавства ВДНЗУ "Буковинський державний медичний університет", Чернівці; лікар судово-медичний експерт КМУ "Чернівецьке обласне бюро судовомедичної експертизи"

\section{Информация об авторах:}

Сивокоровска А-В. С. - аспирант кафедры судебной медицины и медицинского правоведения ВГУЗ Украины "Буковинский государственный медицинский университет", Черновцы; врач судебно-медицинский эксперт КМУ "Черновицкое областное бюро судебно-медицинской экспертизы"

\section{Information about authors:}

Sivokorovska AB. S. - Postgraduate Student, Department of Forensic Medicine and Medical Law, Higher State Educational Establishment of Ukraine "Bukovinian State Medical University", Chernivtsi 